\title{
PERTUMBUHAN KAYU KAMPER DAN HOPEA PADA LAHAN ALANG-ALANG DENGAN TEKNIK PENYIAPAN LAHAN TANAM
}

Growth of Kamper wood and Hopea on Alang-Alang Areas With Prepare Planting Technique

R. Mulyana Omon

Loka Litbang Satwa Primata Samboja

ABSTRACT

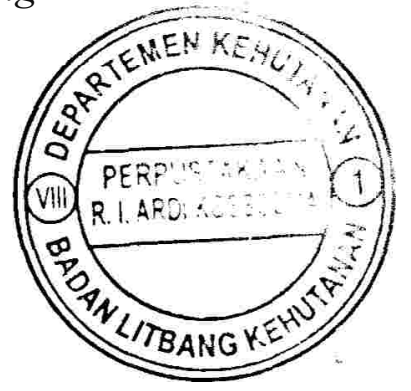

The effect of pre-planting technique on the growth of Dryobalanops lanceolata and Hopea sangal were conducted on alang-alang (Imperata cylindrica) areas in Sungai Wain Protection Forest, Balikpapan, East Kalimantan. The preparation techniques were conducted before planting, using herbicide to kill the alang-alang. The objective of the research was to get information on rehabilitation technique on alang-lang with suitable species of Dipterocarpaceae. Every treatment was observed in a plot $50 \mathrm{~m} \times 50 \mathrm{~m}(0,25 \mathrm{ha})$ with planting distance $5 \mathrm{~m} \times 5 \mathrm{~m}$. Two species and three preparer planting techniques were tested in the experiment. The experiment was arranged as a factorial completely randomized design with three replication. The result showed that species, preparerplanting techniques and interaction between species and preparer planting techniques did not give significant effect to percentage survival ofD. lanceolata and $\mathrm{H}$. sangal. The growth height and diameter ofD. lanceolata was higher than $\mathrm{H}$. sangal as many as $39,79 \mathrm{~cm}$ and $0,38 \mathrm{~cm}$ respectively. While treatment of preparerplanting technique to growth height and diameter with totally sprayed by herbicide treatments were higher than other treatment as many as $35,37 \mathrm{~cm}$ dan $0,38 \mathrm{~cm}$ repectively. Therefore Dipterocarpaceae species plantation, esppecially D. lanceolta and $\mathrm{H}$. sangal have a good aportunity to develop as commercial tree speceis planted in open areas (alang-alang) with totally sprayed by herbicide.

Key word: Alang-alang (1mperata cylendrica), Dryobalanops lanceolata, herbicide, Hopea sangal.

\section{ABSTRAK}

Pengaruh teknik persiapan lahan tanam telah dilakukan terhadap pertumbuhan Dryobalanops lanceolata dan Hopea sangal pada Jahan lang-alang di hutan lindung Sungai Wain, Balikpapan, Kalimantan Timur. Teknik penyiapan lahan dilakukan sebelum penanaman adalah dengan menggunakan herbisida yang bertujuan untuk memusnahkan alang-alang. Tujuan dari penelitian ini adalah untuk mendapatkan informasi teknik rehabilitasi lahan alang-alang dengan jenis yang sesuai dari famili Dipterocarpaceae. Setiap perlakuan dibuat petak coba dengan ukuran $50 \mathrm{~m} \times 50 \mathrm{~m}(0,25 \mathrm{ha})$ dengan jarak tanam $5 \mathrm{~m}$ × $5 \mathrm{~m}$. Rancangan percobaan yang digunakan faktorial $2 \times 3$ dengan pola acak lengkap yang diulang sebanyak 3 kali. Basil penelitian menunjukkan bahwa jenis, penyiapan lahan tanam dan interaksi antara jenis dan 
penyiapan lahan tanam tidak berpengaruh nyata terhadap persen hidūp tanaman. Untuk perlakuan jenis terhadap pertumbuhan tinggi dan diameter yang paling besar adalah $D$. lanceolata, yaitu rata-rata sebesar $\overline{3} \overline{9}, \overline{7} \overline{\mathrm{cm}}$ dan sebesar $0,38 \mathrm{~cm}$. Perlakuan penyiapan lahan tanam dengān cara disemprot totál dengan herbisida lebih besar dibandingkan dengan perlakuan lainnya, yaitu dengan rata-rata pertumbuhan tinggi dan diameter masing-masing sebesar $35,37 \mathrm{~cm}$ dan $0,38 \mathrm{~cm}$. Dengan dernikian penanaman jenis dari suku Dipterocarpaceae khusus dari jenis $D$. lanceolata dan $H$. sangal telah memberi harapan yang baik untuk dikembangkan sebagai jenis komersial untuk ditanam di lahan yang terbuka (alang-alang), dengan perlakuan penyiapan lahan disemprot total dengan herbisida.

\section{Kata kunci : Alang-alang, Dryobāāanops lancéólätä, herbisida, Hopeä sangal.}

\section{PENDAHULUAN}

Alang-alang ([mperata cylindrica L. Beauv). adalah salah satu jenis gulma yang penyebarannya cukup luas terutama di Afrika, China, India, Jepang, Indonesia, Australia dan Eropa Selatan (Moenandir, 1988). Di Indonessia luas areâl yâng ditumbuhi alang-âlang diperkirakan mencapai 98,3 juta ha (Badan Planologi Kehutanan, 2000). Di Kalimantan Timur

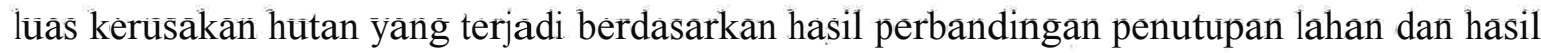
penafsiràn citra satelit selama kurun waktu 12 tahun, adalah 4.513 .905 ha dengan rata-rata làju deforestasi seluas 376.158 ha/tahun (Badan Plānologi Kehütanan, 1997), sebagian dāi areal hutan sudah berubah menjadi padang alang-alang. Jika kerusakan hutan ini dibiarkan

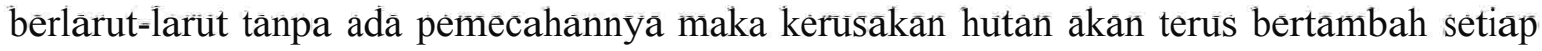
tahunnya. Kerusakan ini diakibatkan oleh tiga faktor, yaitu kebakaran, penebangan liar (illegal loggging) dān perladangan, sehingga menyebabkản lahân tersèbüt ditumbuhi oleh alang-alāng.

Rutan Lindung Süngai Wain merupakan suatu kawasan yang dikelola oleh sebuah Badan yang dinamakan Badan Pengelola Rutan Lindung Sungai Wain (BPRLSW) di bawah Pemerintahan Kota (Pemkot) Balikpapan. Kawasan ini memiliki kekayaan dan kekhasan potensi sumberdaya alam flora dan fauna, juga berperan sangat penting sebagai salah satu pemasok bahan baku air untuk kota Balikpapan. Luasnya setelah dienclave \pm lebih kurang 9.870 hà. Pãda saat ini kawasan yang masih utuh sekitar 3000 ha yang diakibatkan oleh kebakarañ tahün 1982/1983 dan 1997/1998 serta penebangan liar, sehingga diperlukan rehabilitasi lahan alang-alang seluas 730 ha (7,04\%) (Badan Pengelola Rutan Lindung Sungai Wain Balikpapan, 2003).

Lahan yang telah ditumbuhi alang-alang pada umumnya sangat sulit untuk dirubah menjadi lahan produktif baik untuk pertanian maupun kehutanan. Suksesi vegetasi pada lahan alangàlañg biàsānỹa lambăt ătâu kecil kemungkinannya. Hal ini dikarenakan beratnya persaingan dengan tumbuhnya alang-alang atau juga oleh allelophaty yang dapat berpengaruh negatif terhadap perkecambahan biji (Soerianegara, 1976; De La Cruze, 1993, Otsama, 1994 dalam Telkamp, 1997). Untuk menanggulangi masalah ini, perlu adanya campur tangan manusia dālam pèngèlölaan lahan alang-alang menjadi Jahan yang produktif, yaitu dengan penanaman kembali jenis-jenis yang sesuai dengan kondisi lahan. Pada umumnya lahan alang-alang untuk menjadi lāhăn yang produktif ditanam denganjenis-jenis yang mempunyai pertumbuhan yang cepat (fast growing species) seperti Acacaia auruculiformis, Parasianthes falcataria dan 
Eucalyptus sp, kemudian ditanam denganj enis lambat tumbuh (slow growing). Oman (1999); (Oman dan Priadjati, 2004) melaporkan ada beberapa jenis Dipeterocarpaceae yang tahan hidup di lahan yang terbuka seperti $S$. balangeran dan $H$. mengarawan. Kedua jenis tersebut mempunyai morphologi permukaan daun yang licin, sehingga memberikan persentase hidup yang tinggi setelah berumur satu tahun di lapangan, yaitu masing-masing sebesar $90 \%$ untuk S. balangeran dan H. mengarawan sebesar 97\% (Omon, 1999).

Berdasarkan hal tersebut di atas, telah dilakukan pembuatan demplot uji coba jenis Dipterocarpaceae di lahan alang-alang dengan perlakuan penyiapan lahan tanam, yaitu dengan cara alang-alang disemprot total dengan herbisida, jalur tanam yang disemprot dengan herbisida dan cemplongan. Jenis yang digunakan adalah $D$. lanceolata dan $H$. sangal termasuk jenis kayu komersial. Untukjenis $D$. lanceolata terutama di Jawa dikenal dengan nama kayu kamper. Martawijaya et al.(1989), melaporkan jenis ini termasuk kelas kuat I dan kelas awet I yang kayunya banyak digunakan untuk bahan baku pembuatan kontruksi rumah. Penelitian ini berujuan untuk memberikan informasi tentang teknik rehabilitasi lahan alang-alang yang efektif dengan jenis yang sesuai dengan kondisi lahan alang-alang, agar dapat berfungsi kembali secara ekologis dengan jenis dari suku Dipterocarapaceae.

\section{BAHAN DAN METODE PENELITIAN}

\section{A. Lokasi dan Waktu}

Lokasi yang dijadikan tempat penelitian adalah areal rehabilitasi yang ditumbuhi oleh alang-alang di Hutan Lindung Sungai Wain (HLSW) yang letaknya di Km 24 sebelah utara kota Balikpapan atau arah menuju ke Samarinda. Lokasi ini termasuk kelurahan Karang Joang, Kecamatan Balikpapan Utara, Kota Madya Balikpapan, Propinsi Kalimantan Timur. Secara geografis kawasan HLSW terletak antara $01^{\circ} 02^{\prime}-01^{\circ} 10^{\prime} \mathrm{LS}$ dan $116^{\circ} 47^{\prime}-116^{\circ} 55^{\prime}$ $\mathrm{BT}$, dengan topografi mulai datar sampai bergelombang ringan dengan kelerengan mulai dari $0 \%-8 \%$, sedangkan yang curam dengan kelerengan lebih dari $40 \%$. Lokasi penelitian bertopografi datar dengan kelerengan antar 0\% - 5\%, Waktu penelitian mulai bulan Desember 2004 sampai dengan Desember 2005.

\section{B. Tanah dan Iklim}

Kondisi geologi kawasan HLSW terdiri atas formasi kampung baru, formasi Balikpapan dan batuan alluvium dengan jenis tanahnya Utilisol dan Inceptisois (Badan Pengelola Hutan Lindung Sungai Wain, 2003). Menurut Klasifikasi iklim Schmid dan Ferguson (1951) termasuk tipe iklim A dengan curah hujan maximum sebesar $3.770 \mathrm{~mm}$ dan minumum $2.52 \mathrm{l} \mathrm{mm}$, sedangkan kelembaban nisbi maksimum sebesar $91 \%$ dan minimum $78 \%$ dengan suhu udara maksimum sekitar $32^{\circ} \mathrm{C}$ dan minimum $27^{\circ} \mathrm{C}$.

\section{Bahan dan Alat}

Bahan yang digunakan untuk penelitian adalah lahan yang ditumbuhi alang-alang dengan tinggi $1 \mathrm{~m}-1,5 \mathrm{~m}$, sedangkan bahan kimia yang digunakan untuk memusnahkan alangalang adalah herbisida dengan bahan aktif isopropyl aminaglifosfat, dengan dosis yang digunakan sebanyak 8 liter herbisida per 800 liter air per ha (Yasir et al., 2003). Jenis tanaman 
yang digunakan adalah dari suku Dipterocarpaceae, yaitu D. lanceolata dan $H$. sangal berasal dari cabutan dengan tinggi rata-rata $40 \mathrm{~cm}$ yang dipelihara di persemian Loka Litbang Satwa Primata selama enam bulan. Alat yang digunakan untuk pengukuran diameter $2 \mathrm{~cm}$ dari permukaan tanah adalah sigmat (kalifer) dan untuk mengukur tinggi meteran.

\section{Metode}

Petak coba dibuat berdasarkan perlakuan persiapan lahan yaitu disemprot total dengan bahan hibrisida, jalur tanam yang disemprot dengan herbisida dan cemplongan sebagai kontrol, seperti disajikan pada Gambar 1. Luasan petak coba adalah 0,25 ha $(50 \mathrm{~m}$ x $50 \mathrm{~m})$ pada masing-masing perlakuan penyiapan lahan dengan jenis D. lanceolata dan H. Sangal yang diulang masing-masing sebanyak 3 kali. Jadi jumlah petak coba yang dibuat sebanyak $2 \times 3$ x $3=18$ petak atau luas seluruhnya $18 \times 0,25=4,50$ ha. Jarak tanam setiap jenis $5 \mathrm{~m} \times 5 \mathrm{~m}$ ataujumlah tanaman seluruhnya sebanyak $18 \times 100=1.800$ bibit. Pemeliharaan untuk tahun pertama dilakukan setiap 3 bulan selama satu tahun dengan pengukuran diameter dan tinggi dilakukan pada awal setelah ditanam, kemudian diukur kembali setelah berumur satu tahun.

\section{E. Rancangan Percobaan}

Rancangan yang digunakan adalah faktorial $2 \times 3$ dengan pola acak Jengkap dengan perlakuan faktor $\mathrm{A}=$ jenis terdiri dari $\mathrm{A}_{1}=D$. lanceolata dan $\mathrm{A}_{2}=H$. sangal. Untuk faktor $\mathrm{B}$ perlakuan penyiapan lahan tanam yaitu $\mathrm{B}_{1}=$ jalur tanaman yang disemprot dengan herbisida dan $\mathrm{B}_{2}=$ alang-alang disemprot total dengan herbisida, dan $\mathrm{B}_{0}=$ cemplongan sebagai kontrol. Parameter yang akan diukur adalah pertumbuhan diameter dan tinggi, persentase hidup setelah berumur duabelas bulan di lapangan. Analisis data dilakukan dengan menggunakan Analysis of Variance (ANOVA) dengan uji $\mathrm{F}$ dan apabila terdapat perbedaan yang nyata maka dilanjutkan dengan uji lanjutan Tukey pada tingkat kepercayaan 0,01 dan 0,05 (Haeruman, 1975). 


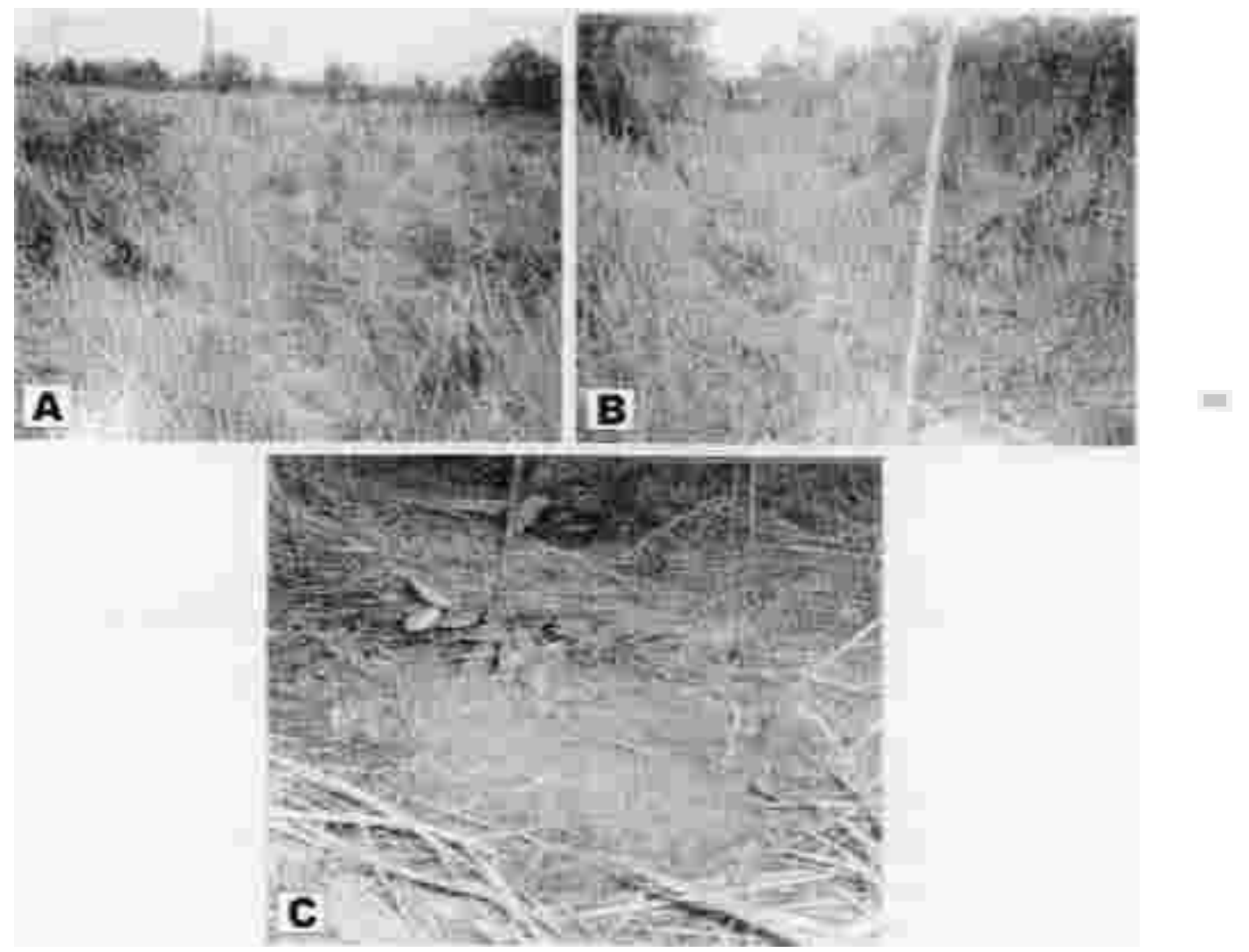

Garnharl. Perlakuan penyiapan lahan tanam (A) sempmr rmal tkngan helbl,ida,(B) jalur tanam discmprot dengan herbisida dan (C) cemplongan pada lahan alaug-ulang.

\section{HASIL DAN PEI $\backslash f f i A H A S A N$}

\section{A. Persen Hidup}

Basil pengamatan rerhadap pcrsen hidup D. Ianceolota setelah berumur 12 bulan ch lapangan menunjukkan bahwa rata-rata persen hidup sebesar $83<\}$ dan untuk $\boldsymbol{A}$. sangal sebesar $80 \%$, sepeni yang disajikan pada Gambar 2 dan Gambar 3 terhadap persen hidup unruk perlakuan penyiapan lahan. Berdasarkan hasil anahsis keragaman dari perlakuan jenis, penyiapan lahan tanarn dan mteraksi anrara jenis dan penyiapan lahan tanarn udak menunjukkan pengaruh yang nyata terhadap pcrsen, walaupun dari hasil analisis kcragarnan pcrlakuan penyiapan lahan tidak menunjukkan pcrbedaan yang nyata terhadap persen ludup, akan rerapi person ludup tanarnan yang iertinggi terlihat pada ranaman dengan perlakuan pcnyiapan lahan yang disemprot total dengan herbrsida, yaitu scbcsar 84,35\% (Gamhar 3). 


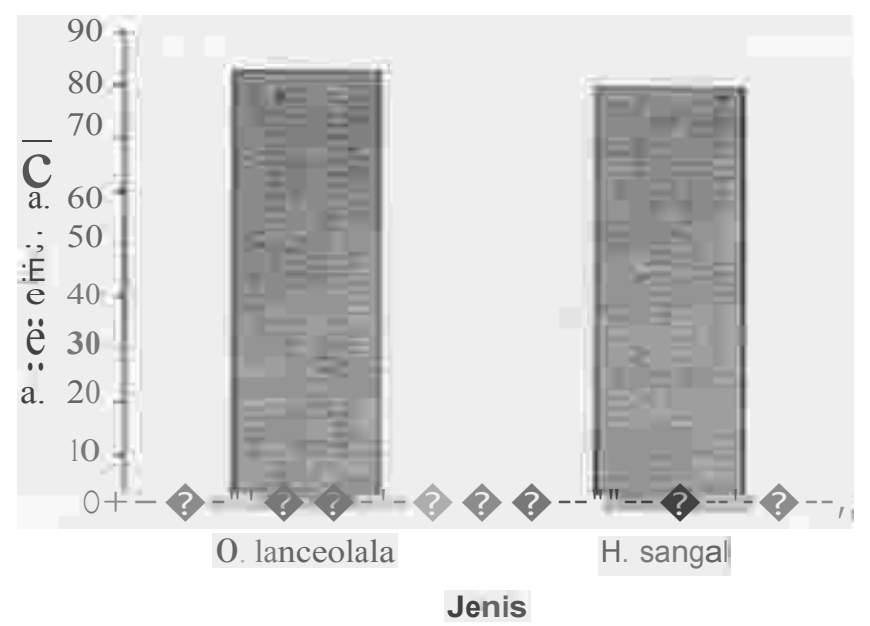

Gambar 2. Person hidup D. lanceolata dan H.. sanga! setclah 12 bulan di lanam di lapangan

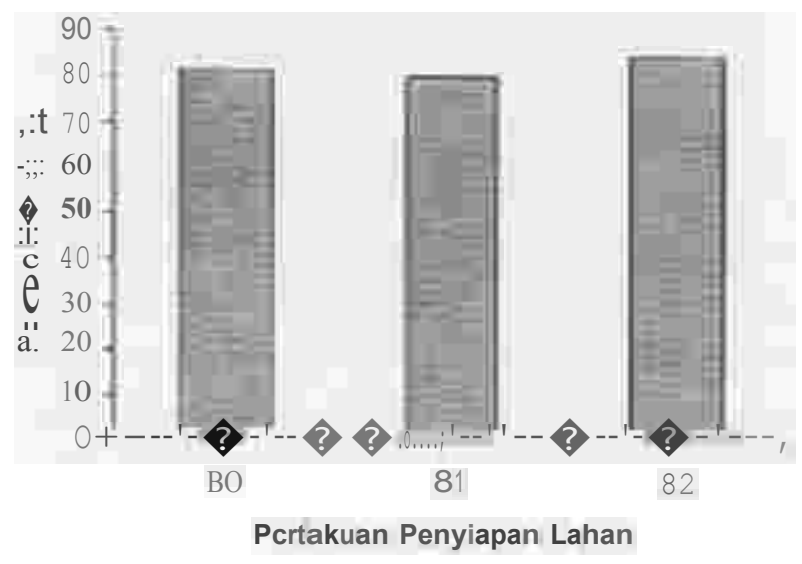

Gambar'>. Person hidup pada perlakuan penyiapan lahan tanam $\mathrm{HO}=$ ccmplongan. $\mathrm{BI}=$ jalur tanam discmprot dengan herbisida clan $82=$ discmprot total dengan herbisidu.

\section{IJ_ Pertumbuhan 1'inggi}

Pcrtumbuhan rnerupakan hasil perkembangan dari bagian siklus kehidupan setiap tanarnan dan berubah dalarn benruk volume dan massa (Oldernan, 1990; Hopkins, 1995). Zaede (1993) bahwa pertumbuhan tanaman merupakan basil dua faktor yang bcrlawanan, yaitu faktor pertama merupakan basil dari naiknya potensial biotik yang tidal.: terbatas dan kedua pertumbuhan mcrupakan hasil penyesuian terhadap tingkungan dan umur. Pertumbuhan (nap) tinggi dan diameter disini adalah hasrl pengukuran akhir dikurungi pengukuran awal. Hasil pengukuran tinggi dipcrolch raia-rata pcrtumhuhan tinggi $D$. lonceolato bcrkisar antara 33 , JO $\mathrm{cm} \cdot 56.29 \mathrm{~cm}$ dan 11. sangal berkisar anrara $13,56 \mathrm{~cm}-26.88 \mathrm{~cm}$ seperti disajikan pada Tabcl I. 
Tabcl 1. Rata-rata pertumbuhan unggr /J. tanceolata dan Hisangal dengan pcrlakuan penyiapan lahan tanam setelah bcrumur saiu tahun di lupangun.

\begin{tabular}{|c|c|c|c|c|}
\hline \multirow[b]{2}{*}{ Jenis } & \multirow[b]{2}{*}{ Ulangan } & \multicolumn{3}{|c|}{ Pcrlakuan persianan lahan tanarn } \\
\hline & & $\frac{\mathrm{BO}}{\text { (Cernplongan) }}$ & $\begin{array}{c}\text { B1 } \\
\text { (Jalur disernprot } \\
\text { herbisida) }\end{array}$ & $\begin{array}{c}82 \\
\text { (Discmprot total } \\
\text { dengan herbisidal }\end{array}$ \\
\hline \multirow{3}{*}{$\begin{array}{c}J \backslash \\
(\text { D. lanceulta) }\end{array}$} & I & 35,73 & 41,51 & 56,29 \\
\hline & 2 & 33,21 & 39,73 & 46.51 \\
\hline & 3 & 38,82 & 33,21 & 33,10 \\
\hline \multicolumn{2}{|c|}{ Rataan D. lanceolta } & 35,92 & 38,15 & 45.30 \\
\hline \multirow{3}{*}{$\begin{array}{c}\mathrm{A} 2 \\
(\boldsymbol{\|}: 1111 \mathrm{xal})\end{array}$} & 1 & 16,86 & 16.54 & 23.47 \\
\hline & 2 & 13,56 & 14.92 & 26,88 \\
\hline & 3 & 17.36 & 18,26 & 25,95 \\
\hline \multicolumn{2}{|c|}{ Raraan Hsangal } & 15,93 & 16.57 & 25,43 \\
\hline \multicolumn{2}{|c|}{ Rataan } & 25.92 & 27,36 & 35,37 \\
\hline
\end{tabular}

Husrl analisis sidik ragam rnenunjukkan bahwa perlnkunn [cnis bcrpcnguruh sang,u nyata tcrhadup penumbuhan Illlggl. sedangkan penyiapan lahan tanaman bcrpengaruh llyat; |lcl hudap penumhuhan ll1lgg1. Intcruksi Jlllara jenis dan penyrapan lnhan udak berpeng.uuh nyura tcrhadap pcuumbuhun tinggi. 1111111k jcms $V$. lunceoltuu pcnurnbuhun ungginyn IC'blh bcvar dibandingkan dengan /I :,all "'. yaitu scbesar )9,79 cm scpern drsaukan pudu Gall11>al I. 1 111111.. pcrsiapan lahan tanarn yang lerhaik, pcrlu dilakukan uji beda nyata Tukcy scpcrn disajik.m pad:, (i $\$ \mathrm{mh}, 11$ 'i.
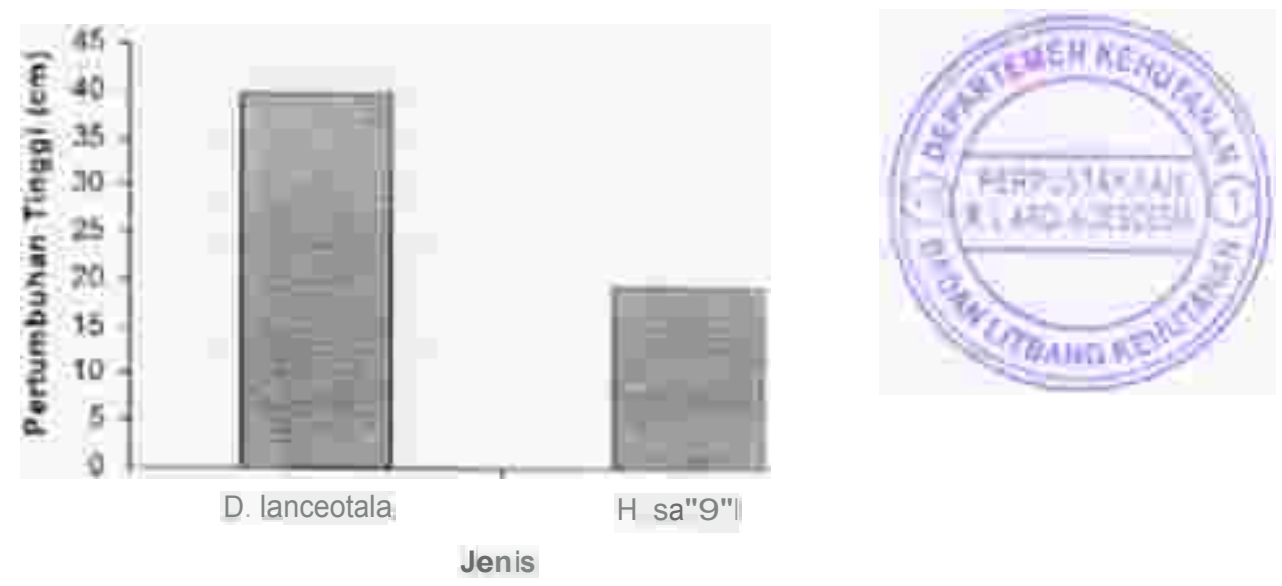

Gamhar 4. Pcrtumbuhan tinggi D. lanrrataa dan H. sm1g11/ scteluh 12 bulan ditanam di lapangan. 


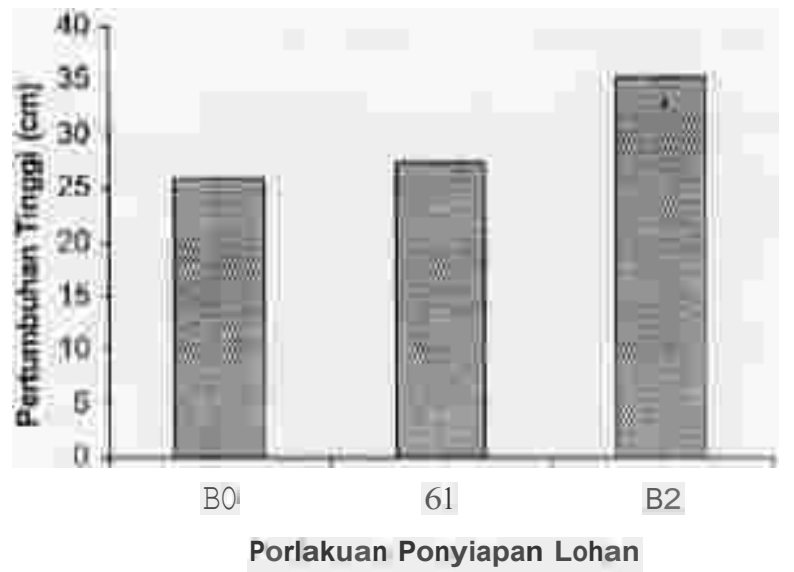

G.I11lbar 5. Pertumbuhan tinggi dengan perlukuun pcnyiapan lahan $00=$ cemplongun: $131=$ julur tunum discrnprot dengan herbisidu dun B2 = discrnprot total dengan herbisida,

Hnsil uji beda nyata Tukcy dari Garnbar 5 dengan nilai W (0.05) scbcsar 10,40 mcuunjukkan bahwu unluk pcrtumhuhan ti11ggi yang paling bcsar dcngan pcnyiupun lahun tunum dengan earn disemprot total dibandingknn dengan perlukuun penyiapan luhun ianam lainnya, yauu scbcsar $35,37 \mathrm{~cm}$. Waiaupun dengun penyiapan lahan dengau jalur tllialll yang discmprot tiduk berbedu nyata.

\section{C. l'cl'tumbnluln Ilinmeter'}

IIasil pengukurun terhadap pertumbuhan diameter diperoleh 1-.lla ruta pcrtumbuhun diameter /). laurrolnta bcrkisar nnrnra 0,30 cm - 0.Ci l cm dan $N$. "'"' 'gal bcrkisar anrnrn 0,17 $\mathrm{cm}-0,26 \mathrm{~cm}$ scperti disajikan padu Tubcl 2. Hasil unulisi» cr.lg, „lmlll menunjukkun bahwa jcnis dun pcnyiapnn lahan tunarn herpengnruh sangal ny:ua rerhndap pcnumhuhan diameter. Interaksi antaru jcnis dan pcnyiupan luhan tidak menunjukkun pengarult yang ny, lla icrhadap pcrtumbuhan diameter kcdua jcrus. tImuk pcrnunbuhan diameter I). touceott « Icbih bcsnr dibandingkun dcugun //. wlllgll/ yaitu scbesar 0,38 cm (Tubel 2 dun Gumbnr 5). Uruuk perlakuan penyinpnn Inhnn ynng baik pcrlu dilakukan uji hcdn Tukey. Tla@il uji hcda nynrn Tukcy dengan nilai $\mathrm{W}(0,05)$ scbcsai 0,10 incnunjukkau pcrlakuan pcnyiupan luhuu unuun dcngan discmprot total tclah mcmbcrikan pcrtumhuhan diameter Ichih hesar dibandingkan clcngan pc, lakuan lainnya. yaitu scbcsar 0.38 c111 scpcui disaji kun padu Garnbar 6. 
1abel 2. Rata-rata perrumhuhan diameter D. lanceolata dan //. sangal screlah berurnur satu tahun di iapangan.

\begin{tabular}{|c|c|c|c|c|}
\hline \multirow[b]{2}{*}{ Jonis } & \multirow[b]{2}{*}{ Ulangan } & \multicolumn{3}{|c|}{ Perlakuan Persiapan lahan tanam } \\
\hline & & $\begin{array}{c}\mathrm{BO} \\
\text { (Cemplougan) }\end{array}$ & $\begin{array}{c}\text { Bl } \\
\text { (Jalur discmprot } \\
\text { herbisida) }\end{array}$ & $\begin{array}{c}82 \\
\text { (Disemprot tota I } \\
\text { dennan herbisida) }\end{array}$ \\
\hline \multirow{3}{*}{$\begin{array}{c}\mathrm{A} 1 \\
\text { (D. lanceolta; }\end{array}$} & 1 & 0.32 & 0.37 & 0,61 \\
\hline & 2 & 0.28 & 0.35 & 0.50 \\
\hline & 3 & 0.30 & 0.33 & 0,39 \\
\hline \multicolumn{2}{|c|}{ Rataan D. lunceolta } & 0,30 & 0.35 & 0,50 \\
\hline \multirow{3}{*}{$\begin{array}{c}\mathrm{A} 2 \\
\text { (II.sallgaf) }\end{array}$} & 1 & 0,21 & 0,17 & 0.26 \\
\hline & 2 & 0,17 & $\left.0, J^{\prime}\right)$ & 0,25 \\
\hline & 3 & $0 ! 21$ & 0.19 & 0,26 \\
\hline \multicolumn{2}{|c|}{ Rataan H.sammI } & 0,20 & 0,18 & 0.26 \\
\hline \multicolumn{2}{|c|}{ Rataan } & 0,25 & 0.27 & 0,38 \\
\hline
\end{tabular}

Bcrdasarkan hasil rcrscbut di alas terlihat ad,111y,1 pcrbcduan pcnumhuhan 1i113gi dan diameter tcrhadup kedua jcnis, yaitu $O$. lanreoluta lcbih baik dibandingkan $\mathrm{fl}$. sangal. Perbcdunn ini dikarcnnknn taktur geuctik dari kedua jcnis tcrscbut yang bcrbcda akan ICUIJ!t jcnis dapat di kcmbungkun untuk dhanam di lahan tcrbuka (ulung-utung). karcnu ruernpunyui kurukrerisiik morfologi daun yang Mln1.1 yaitu pcrrnukaun licin, sehi1133n pada waktu pel1111lnmnll proses pcnguupun daun (uunpirasi) ridak tcrlalu bcsai dib, $111 \mathrm{di11} \mathrm{gk}$, 111 pcrmukuan kasur scpcni jcnis $S$ trprosui« clan S. smithiana. Dikcmukan Devlin dun Wrthum (IJJIU) sclain tukror lingkungan (cahaya, tcmpcruurr, angin) yang nicmpcnguruhi trunpirasi juga pcrmukaan dn un (IPl, fsurface).

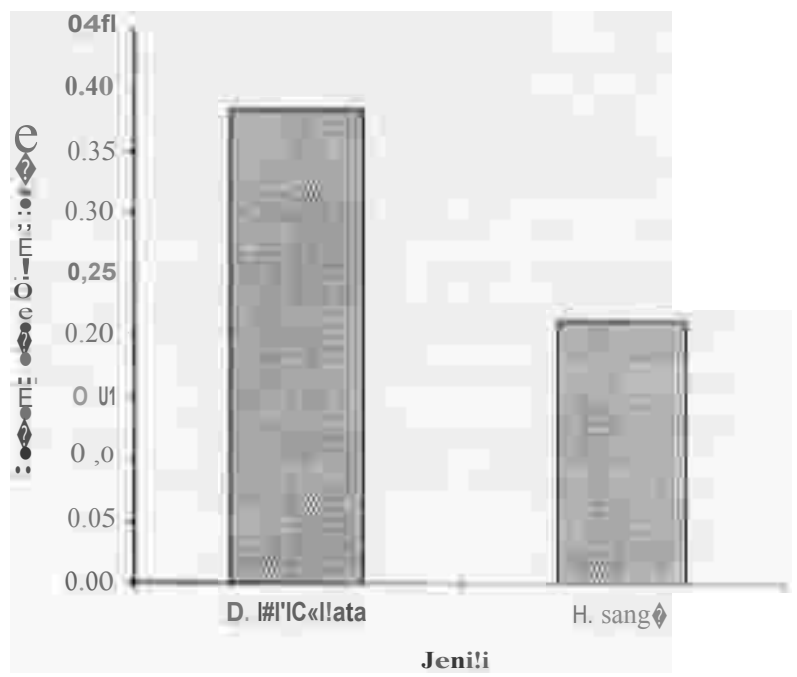

Gambar 6. Penumbuhan diameter l). lanceolata dan H. sanga! setelah l'.l. bulan ditanarn di lapangan, 


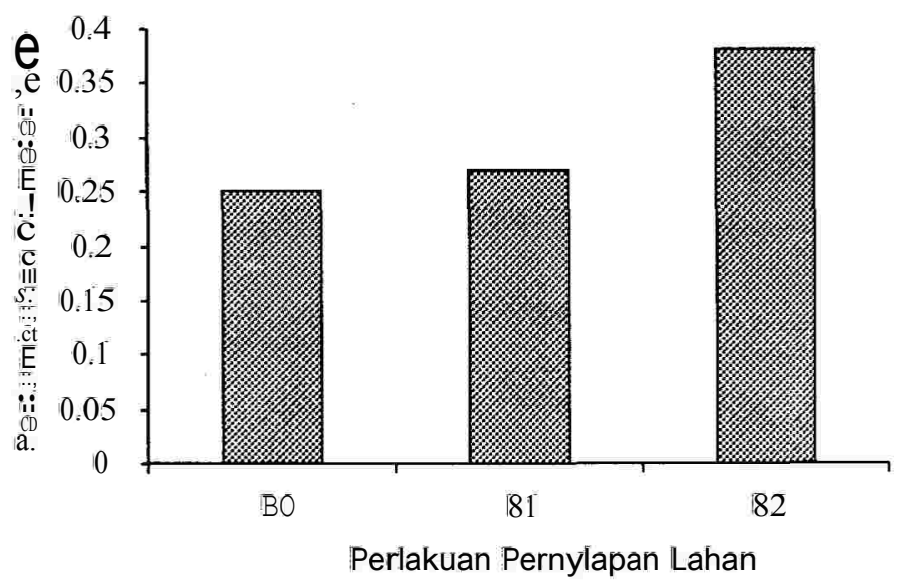

Gambar 7. Pertumbuhan diameter dengan perlak:uan penyiapan lahä $\overline{\mathrm{B}} \mathrm{O}=$ cemplongan, $\overline{\mathrm{B}} \mathrm{l}=$ j alur tanam disemprot dengan herbisida dan $\overline{8} 2=$ disemprot total dengan herbisida setelah 12 bulan ditanam di lapangan.

Untuk. perlakuan penyiapan lahan yang baik terhadap pertumbuhan diameter dan tinggi dari kedua jenis Dipterocarpaceae adalah dengan cara disemprot total dengan herbisida dibandingkan dengan perlak:uan lainnya. Perbedaan ini dikarenak:an akibat penyemprotan dengan herbisida alang-alang menjadi cepat mati, sehingga tidak: ada persaingan pengambilan unsur hara dalam tanah antara tanaman pokok (D. lañcéolätä dan $\bar{H}$. saingal) dengan alangalang. Selain itu, alang-alang dari hasil penyemprotan menjadi membusuk. dapat digunak:an sebagai pupuk hijau untuk tanaman pokok dan pembusukkan alang-alang juga dapat menyebabkan tempertur tanah menjadi rendah dan sangat baik untuk perkembangan mikoriza. Untuk lebih jelasnya pertumbuhan dari kedua jenis ditanam dengan perlakuan cemplongan (kontrol) dan perlak:uan alang-alang disemprot total setelah dua belas bulan di lapangan dapat di lihat pada Gambar 8 dan Gambar 9.

Berdasarkan uraian di atas, pengelohan lahan yang tidak: produktifuntuk ditanam dengan jenis komersial, perlu adanya campur tangan manusia dalam pengelolaannya yaitu dengan cara menyiapkan lahan tanam dengan disemprot total dengan herbisida dan pemelihan jenis yang sesuai dengan kondisi alang-alang. MenurutMurniati (2002) bahwa pembersihan alangalang dengan penyemprotan herbisida dapat diterima dalam pengolahan lahan alang-alang menjadi lahan yang produktif. Secara keseluruhan bahwa jenis dari Dipterocarpaceae khususnya jenis $D$. lanceolätä dan $H$. sangal dapat tumbuh dengan baik dengan persentase hidup tanaman lebih dari $80 \%$ setelah satu talrnn ditanam Diharapkan kedua jenis ini dapat dikembangkan untuk di tanam di lahan terbuka (alang-alang), karena jenis ini dapat dimasukkan ke dalan jenis intoleran. 

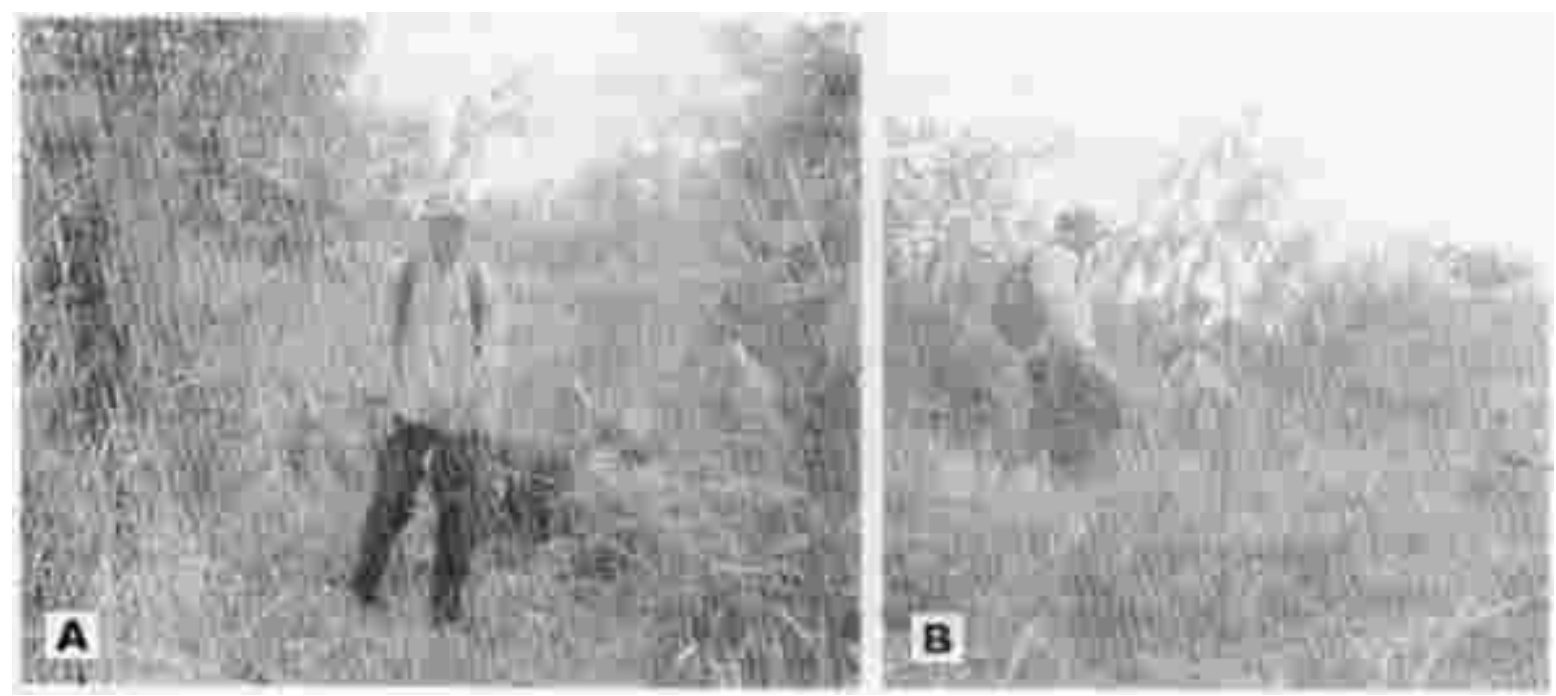

Gumbnr 8. Jc1lls D. luncrtota ckngnn p, rlal..u.111 c.:11lplonl1,111 (A) dun p.:d.il..u.111 al,111u-alun discmpr.»1,>lal (RI -..1.-t, I11 s.|t|J tahun duanam drlapangun
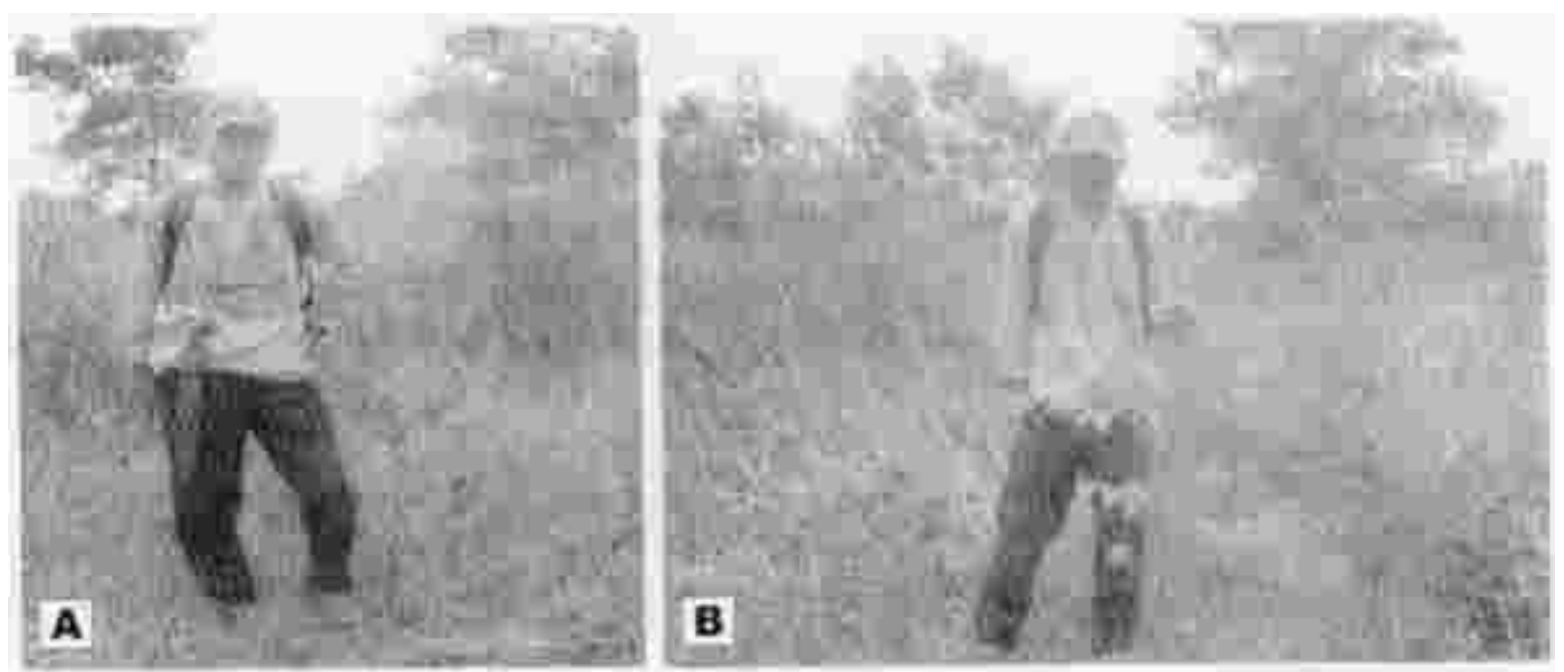

G:1111hJr 9. Jcms H..sangat dengan pcrlakuan ccmplongan (A) d:111 pcrlakuun alnng-nIng disempror total ; ;ctclnh I tnhun duanam th lapangan

\section{KESLItI'IJL IN}

I. Pcnyiapan lahan tanarn dengan cara disemprot total dengan herbisida telah memberikan pcningkaian penumhuhan unggi clan diameter masmg-rnasmg scbesar i5 cm dan (). 18 cm untuk lems kayu kampcr (Drvobalunops Iunccolatu).

Kcdua rems dari suku Dipctcrocarpaccac. yaitu $D$, lanccoluta d,11l H sanuat dihai apknn dapat dikembang uruuk ditanam di lahan terbuka (alang alang) dengan pcrsen hidup lebih dari $80^{\prime} 7$ n. 


\section{DAFTAR PUUSTAKA}

Badan Planologi Kehutanan 1997. Departemèn Kẹhütanañ dān Pērkēbunnān, Jakārtai İTIO (International Tropical Timber Organization). 1990. Rèhabilitation of logged-ōvèr

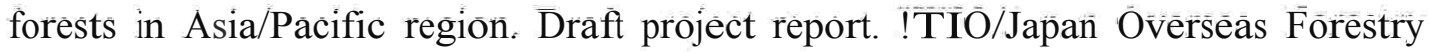
Consultants Association (JOFCA). Yocōhāmà. 95 pp.

Badan Planologi Kehutanan. 2002. Indikasi Kawasāan Hutan dan Lahan Yāñ̄ Pẹrlū Dilakūkān Rehabilitasi. Departemen Kèutanan, Jakarta:

Badan Pengelola Hutan Lindung Sungai Wain. 2003. Pembagian Blok Pengelolaan Kawasan Hutan Lindung Sungai Wain, Balikpapan. Ekpose dan Diskusi, Balikpapan tanggal $\overline{8}$ Mei 2003.

Devlin, RM. dan Witham, F.H., 1983. Plants Physiology. Fourth Edition. Bilmont, Clifornia, Adivisionof Wadoworth, Inc. P. 73-94.

Haeruman, H., 1975. Prosedure Analisa Rancangan Percōbāan. Bagian Pẹrtama. Bàgiān Perentjanaan Hutan. Departemen Managemen Hutan, Fakultas Kehutanan, $\overline{\mathrm{IPB}}$, Bogor.

Hopkins, W.G. 1995. Introduction to Plant Physiology. John Wiley \& Sons Inc̄. New York, USA.

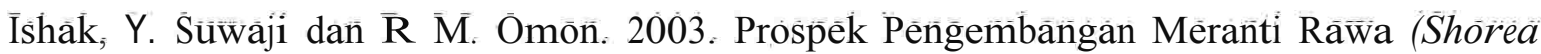
balangeran Korth) pada Lahan Alang-alang. DIPTEROKARPA Vol 7 No 1. Balai Penelitian dan Pengembangan Kehutanan Kalimantan.

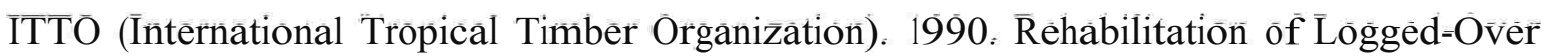
Forests in Asia/Pacific Region. Draft project report. !TIO/Japan Överseàs Forēstry

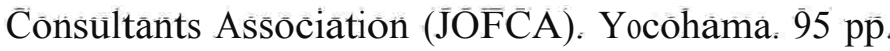

Martawijaya, A. I. Kartasujana, YI. Mandang, S. A. Prawira dān K. Kadir,, 1989. Atlas Kayu Indonesia Jilid II. Badan Litbang Kehutana, Bogor Indonesia. p. 15-19.

Moenandir, J. 1988. Pengantar ilmu gulma dan pengendalian gulma. Universitas Brâwijaya Malang. 122 pp.

Murniati. 2002. From Imperata cylindrica Grass Lands to Productive Agroforestry. $\overline{\mathrm{P}} \mathrm{h} . \overline{\mathrm{D}}$.

Thesis, The Wageningen University, The Netherlands. Tropenbos Kalimantan. Series 9. p. 172.

Oldeman, RA.A., 1990. Forests: Elements of Silvo,ogy, Heidelberg, Germany.

Omon, R.M. 1999. Pertumbuhan Sepuluh Jenis Dipterocarpaceae Di Areal Hutan Tanaman Industri PT. INHUTANI I, Batu Ampar, Balikpapan. Buletin Penelitian Kehutanan, BPK Samarinda Vol.14 No 1. p.1-11.

Ōmon, $\bar{R}$ M. dan A. Priajati. 2004. Perttumbuhan Meranti Padā Program Rehabilitasi Lahan Alang-Alang (Imperata cylindrica) Dengan Sistim Tumpang sari. Vol 1, No 3.Jurnal Penelitian Puslitbang Rutan dan Konseravasi Alam. 
Schmidt, F.H dan J.H.A. Ferguson,1951. Rainfall types based on wet and dry period ratios for Indonesia with Western New Guinea Verhand. No.42. Kementrian Perhubungan, Djawatan Meteorologi dan Geofiska, Jakarta.

Telkamp. G. W. 1997. First Year Results of The Elimination Trial Involving 31 lndigienous and 10 Exotic Species for The Rehabilitation of Alang-Alang (Imperata cylindirica) Dominated Grassland in East Kalimantan, Indonesia. Wanariset Tèchnical Report 1997R2. The International MOF Tropenbos-Kälimantan Project.

Zaede, B., 1993. Analysis of Growth Equations. Forest Science. p. 594-616. 